\title{
Why Are There No Locative Conjunctions in Spanish?*
}

\author{
María Victoria Pavón Lucero \\ Universidad Carlos III. \\ Departamento de Humanidades: Filosofía, Lenguaje y Literatura \\ C/ Madrid, 126. 28903 Getafe (Madrid) \\ mvpavon@hum.uc3m.es
}

Received: April 82010

Accepted: September 252010

\begin{abstract}
The main purpose of this paper is to explore why there are no locative subordinating conjunctions in Spanish. As we will see, the absence of this type of conjunctions is due, on the one hand, to its lexical-grammatical properties and, on the other hand, to the semantic structure of locative expressions. Adverbial subordinating conjunctions share properties with both lexical and functional heads. They share with complementizers the requirement that they take an extended projection of the verb as their complement. At the same time, just like lexical categories such as prepositions, they have lexical content and are associated with an argument structure. In this sense, adverbial subordinating conjunctions can be seen as semantic functions which can express several types of relations and take events or states as their internal argument. However, the semantic structure of spatial expressions must contain a place function that takes as argument a conceptual constituent corresponding to the semantic category Thing. The reason for the non-existence of locative subordinating conjunctions is, then, the incompatibility between categorial and semantic requirements in their complement.
\end{abstract}

Key words: subordinating conjunctions, prepositions, complementizers, relative adverbs.

\section{Table of Contents}

\section{Introduction 4. Adverbial free relative clauses.}

2. Adverbial subordination from a semantic and syntactic point of view Differences with adverbial clauses headed by conjunctions

3. Adverbial clauses headed

5. The semantic of Place by conjunctions

\section{Concluding remarks}

References

* This paper results from a wide revision of an early version presented to the IV Congreso de Lingüística General (see Pavón Lucero, 2003a). I wish to thank Yuko Morimoto and Isabel Pérez Jiménez for helpful comments and suggestions. I thank also an anonymous reviewer for helping me recognize, an respond to, many of the limitations of this work. 


\section{Introduction}

Adverbial subordinating conjunctions form a controversial class of words whose syntactic behaviour exhibits properties in common both with lexical and functional categories. The limits of this class of words, along with their categorial status, is still an unclear matter: they have been considered either a subclass of prepositions or a subclass of complementizers. Subordinated sentences introduced by this type of conjunctions may express a considerable number of semantic relations in Spanish, from which spatial relations, among others, are excluded. However, there is another class of subordinated sentences, generally grouped together with adverbial subordinated sentences, which can express the meaning of location: adverbial free relative clauses.

The purpose of this paper is to explore why there are no locative subordinating conjunctions in Spanish. We will begin, in section 2, by offering a general outlook of adverbial subordination. In section 3, we will discuss the categorial status of adverbial subordinating conjunctions and, consequently, the syntactic structure of subordinated sentences headed by them. We will review the hypothesis that this class of conjunctions is a subclass of prepositions, as well as the problems posed by this hypothesis. We will also review their similitudes and differences with complementizers and, finally, we will assume the proposal, by Haumann (1997), that adverbial subordinating conjunctions are a hybrid category, which share properties both with prepositions and complementizers.

In section 4, we will concentrate on the structure of adverbial free relative clauses and we will compare this structure with that of sentences headed by subordinating conjunctions. Finally, in section 5, we will account for the semantic structure of both types of constructions and we will see that the fact that there are no locative subordinating conjunctions is due to the incompatibility between the semantic structure of locative expressions and the syntactic structure of sentences headed by adverbial subordinating conjunctions. The present study will focus on the grammar of Spanish. However, if our proposal is correct, it would be predictable that there are no locative subordinating conjunctions in any other language, and we will outline some indications in some other European languages that this prediction is in fact correct.

\section{Adverbial subordination from a semantic and syntactic point of view}

In many traditional and scholarly Spanish grammar books and references, the term adverbial subordination covers several syntactic structures. All of the following constructions have been treated as sentences that contain an adverbial subordinated clause (in italics in the examples): 
(1) a. Mantenía los ojos muy abiertos, para que supieran que He-kept the eyes wide open so that they-would-know that estaba vivo. he-was alive.

'He kept his eyes wide open so that they would know he was alive.' (Mario Vargas Llosa, La fiesta del chivo; example from CREA)

b. Pero fui algo antes de nacer y seré algo But I-was something before of to-born and I-will-be something después de que mi cuerpo se disuelva. after of that my body - disintegrates'

'But I was something before I was born and I will be something after my body disintegrates.'

(Alejandro Jodorowsky, La danza de la realidad. Chamanismo y psicochamanismo; example from CREA)

c. La Rotunda tragó completa su ración de presos y los

La Rotunda swallowed complete her portion of prisoners and the cautivos se quedaron donde estaban.

captives - remained where they-were

'La Rotunda completely swallowed her portion of prisoners and the captives remained where they were.'

(Francisco Herrera Luque, En la casa del pez que escupe el agua; example from CREA)

d. Si hubiéramos vivido con él, nunca se hubiera puesto If we-would-have lived with him, never - he-would-have become enfermo.

sick

'If we would have lived with him, he would never have become sick.'

(Manuel Martínez Mediero, Las largas vacaciones de Oliveira Salazar; example from CREA)

Despite the different semantic relations that each one of the highlighted clauses expresses with respect to the main clause (purpose in (1a), temporal location in (1b), spatial location in (1c) and condition in (1d)), they correspond to very different syntactic structures. In (1a), there is a PP: the preposition para has a finite substantive subordinated clause as a complement. As we can see in (2), the complement of para could be a non-finite (infinitive) clause or a neutral demonstrative pronoun, without changing the purposeful meaning of the construction:

(2) a. Mantenía los ojos muy abiertos, para mostrar que estaba vivo. He-kept the eyes wide open, in-order to-show that he-was alive

b. Mantenía los ojos muy abiertos, para eso. He-kept the eyes wide open, for that 
The temporal clauses in (1b) are adverbial phrases headed by the adverbs antes ("before") and después ("after"). These adverbs take a complement, introduced by the preposition de ("of"), which may correspond to a finite or non-finite (infinitive) clause ${ }^{1}$, as is shown in (1b) (después de que mi cuerpo se disuelva and antes de nacer, respectively) or, as we can see in (3a) and (3b), to a pronoun or a DP:
a. Fui algo
antes de eso.
I-was something before of that
'I was something before that.'

b. Seré algo después de mi muerte.

I-will-be something after of my death'

'I will be something after my death.'

In (1c), the subordinated clause is a free relative introduced by the locative relative adverb donde; in (1d), finally, the conditional clause is introduced by the subordinating conjunction si. These are the two types of subordinated sentences we are concerned with here, hence their structure will be discussed in the following sections. It must be noted that, if the term adverbial subordination had to be restricted to a particular syntactic structure with distinctive features from any other class of constituents, that would be (1d); that is, the construction headed by subordinating conjunctions. As we will see, the properties of this class of words, and its classification regarding other syntactic categories is a controversial matter in linguistic theory. On the other hand, this structure excludes some of the semantic notions traditionally captured under adverbial subordination. Concretely, these structures exclude spatial meaning, which can be expressed, however, by means of adverbial relative clauses. As we have already stated, the main purpose of the following sections will be to explain the reasons for that fact.

\section{Adverbial clauses headed by conjunctions}

As has been previously noted, the categorial status of subordinating conjunctions and, consequently, the structure of the clause they introduce, is a controversial matter. Different proposals have been made in order to classify this type of conjunctions. Some of these proposals have in common their attempt to include subordinating conjunctions in other types of syntactic categories: basically, complementizers and prepositions. Nevertheless, we will assume a different perspective that considers them an independent hybrid syntactic category, which combines properties of lexical and functional heads.

1. When the complement is a finite clause, the preposition de is optional, so, in (1b), después que mi cuerpo se disuelva would be possible as well. This fact is related to the mixed nature of antes and después, as temporal adverbs and comparative words. For this reason, antes and después can form comparative constructions with a noun preceeded by que, and in this case the preposition would produce ungrammatical sentences: Marina terminó el artículo antes (*de) que Alfredo ('Marina finished the paper sooner than Alfredo'). See, in this respect, García Fernández (1999: 48.6) and Real Academia Española (2009: 31.14d ff.). 


\subsection{Adverbial subordinating conjunctions as complementizers}

Traditionally, conjunctions have been considered a part of speech made up of two main classes: coordinating and subordinating conjunctions. The subclass of subordinating conjunctions is further subdivided into those that introduce substantive subordinated sentences (in Spanish, que, 'that', and the conjunction si, 'if', that introduces subordinated interrogative clauses ${ }^{2}$ ), as well as the conjunctions that head adverbial subordinated sentences; that is, for the case of Spanish, simple units like conditional $s i^{3}$ ('if') or causal como ('since'), and a large number of complex units such as causal porque or puesto que ('because, since'), temporal en tanto que ('while, insofar as'), concessive aun cuando ('even if'), etc. An accurate description of this classification, as well as of the problems it poses, is available in Real Academia Española (2009: 31.1).

According to this classification, adverbial subordinating conjunctions would form part of the same syntactic class as complementizers. The hypothesis that adverbial subordinating conjunctions are complementizers has been maintained as well by authors such as Hendrick (1976) or Lasnik and Saito (1972). Obviously, complementizers and adverbial subordinating conjunctions have in common the fact that both take a sentential complement. Moreover, as the mentioned authors point out, this hypothesis explains why sentences such as the ones in (4) and (5) are ungrammatical in English and Spanish, respectively:

(4) a. *Unless that the strike has been called off, there will be no trains tomorrow.

b. *She watered the flowers because that they were dry.

c. *Since that the weather has improved, the game will be held as planned.

$$
\text { (Examples from Haumann (1997: 50)) }
$$

2. Interrogative si has been traditionally considered a subordinating conjunction, but some authors have included it in the same class as interrogative pronouns or adverbs. This proposal can be traced back to some traditional Spanish grammarians such as Bello. This author (see Bello, 1847:§ 415) considers $s i$ to be a relative adverb which he places in relation to conditional si ('if') (relative adverb for Bello) and affirmative sí ('yes') (which is categorised by Bello as a modal adverb). More recently, Rigau (1984) argues that interrogative si in Catalan is an interrogative adverb, showing that it behaves like other interrogative words, like quan ('when'), que ('what') or qui ('who'), and differs from complementizer que ('that'). See also Real Academia Española (2009: 22.2p) for some properties of interrogative $s i$ in Spanish that make it different from other interrogative words.

3. Some authors have proposed that (some) subordinating conjunctions are relative adverbs. As we have just seen in the previous footnote, this is Bello's proposal. This author considers their ability to link analogous constituents to be a defining property of conjuntions (see Bello 1847: $\$ 74$ ); consequently, only coordinating conjunctions would properly be conjunctions, whereas subordinating conjunctions would form part of the same grammatical class as relative adverbs. Among other recent proposals, Haegeman (2007) considers conditional subordinating conjunctions to be relative adverbs, presenting arguments based on morphologic and ethimologic sources of some conditional conjunctions in French and German. Nevertheless, in section 4 we will argue that adverbial subordinating conjunctions (such as conditional si) and the sentences they introduce show a syntactic behaviour which is different, in many important respects, from that of sequences introduced by relative adverbs. 
(5) a. *Volvería a viajar a Australia si que pudiera permitírmelo. I-would-again travel to Australia if that I-could afford-it 'I would travel to Australia again if I could afford it.'

b. *Como que no contestaste a mi carta, pensé que no estabas Since that not you-answered - my letter, I-thought that not you-were interesado en el trabajo. interested in the job

'Since you didn't answer my letter, I thought you were not interested in the job.'

c. *No pudimos evitar que se saliera con la suya, aun cuando que Not we-could keep-from that he-got-away-whit-it, even thought that la mayoría no estábamos de acuerdo.

the majority (of us) not we-agreed

'We couldn't keep from him getting away with it, even though most of us didn't agree.'

Taking into account the hypothesis presented, the reason for the ungrammaticality of these sentences would be the presence of two words of the same class occupying the same syntactic position: the subordinating conjunction and the complementizer (that in English, que in Spanish). Nevertheless, we can show some important differences in Spanish between both classes of words; differences which have to do with the positions that the structures introduced by them may occupy in the sentence.

Subordinated clauses introduced by the complementizer que in Spanish must occupy argumental positions, as complements of lexical categories, such as $\mathrm{P}$ or $\mathrm{V}$, as well as the Subject position, as the examples in (6) show. On the contrary, adverbial subordinated clauses like those in $(7 \mathrm{a}, \mathrm{b})$ are adjuncts; that is, they occur in non-argumental positions (they are not lexically selected by a lexical head):

(6) a. $\mathrm{Su}$ decisión depende de que le renueven los

$\{$ His/her $\}$ decision depends on that to- $\{$ him/her $\}$ they-renew the papeles.

identification-papers

' $\{$ His/her $\}$ decision depends on $\{$ his/her $\}$ identification papers being renewed.'

b. Creo que no podemos esperar más.

I-think that not we-can to-wait more

'I think we can't wait any longer.'

c. Que estés aquí significa que no tienes que estudiar hoy.

That you-are here means that not you-have-to-study today

'The fact that you are here means that you don't have to study today.' 
(7) a. María no vendrá a la fiesta si no se lo pides tú. María not will-come to the party if not to-her it ask you 'María won't come to the party if you don't ask her.'

b. Si todo va bien, llegaremos sobre las ocho.

If everything goes all right, we-will-arrive by the eight

'If everything goes all right, we will arrive by eight.'

Adverbial subordinating conjunctions exhibit, in this way, contradictory behavior. From the point of view of the internal structure of the constituent they head, this kind of conjunctions is similar to complementizers. Nowadays, the subordinated sentences headed by complementizers and those headed by adverbial subordinating conjunctions are completely different in terms of the position they may occupy with respect to the main clause. For more arguments regarding the differences between complementizers and adverbial subordinating conjunctions, see Haumann (1997: 3.2).

\subsection{Adverbial subordinating conjunctions as prepositions}

As we have already mentioned, some authors, such as Jackendoff $(1973,1977)$, Emonds (1985) and Larson (1990), have proposed that adverbial subordinating conjunctions are prepositions. A similar hypothesis had been proposed previously by authors such as Jespersen (1924), Hjemslev (1928) or Pottier (1962).

Basically, this hypothesis defends the position that prepositions, adverbial subordinating conjunctions and some adverbs are subclasses of prepositions which differ in their subcategorization properties. For example, instead of considering, as is traditionally maintained, that before and after are polycategorial words that, depending on the context, can function as a preposition, (8a), an adverbial subordinating conjunction, $(8 b)$, or an adverb, $(8 c)$, it would be proposed that in each case we have the same category. Before and after would be prepositions that can take a DP as a complement, as in (8a), or a sentence, as in (8b); they can also be used intransitively, that is to say, with no explicit complement, as in $(8 \mathrm{c})$ :

(8) a. He did the washing-up \{before/after\} their arrival.

b. He did the washing-up \{before/after\} their parents arrived.

c. Their parents arrived at seven, and he did the washing-up \{before/after .

On the other hand, an adverb like, for example, always, could be considered an intransitive temporal preposition, that is, a temporal preposition that takes no complement. As to traditionally considered adverbial subordinating conjunctions, such as unless or because in (9), they could be accounted for as prepositions that invariably subcategorize a sentential complement:

(9) a. The planet's future is questionable unless developed countries improve global strategic collaboration.

b. I cannot check my messages because the computer is out of order. 
This is, however, a problematic hypothesis in many respects. In the following, we will see some problems for its application to Spanish (see Haumann, 1997: 3.3 for discussion based on data from English). These problems have to do, basically, with the syntactic (sentential) category that prepositions, on the one hand, and adverbial subordinating conjunctions, on the other, take as a complement.

In Spanish, if a preposition takes a sentential complement headed by a finite verb, the sentence must be introduced by the complementizer que ('that'), as is shown in $(10 \mathrm{a}, \mathrm{b})$. Nevertheless, as we have seen in (5a), que cannot introduce the sentential complement of an adverbial subordinating conjunction, as the conditional si ('if'), (10c):

(10) a. No contaba

con que la perversidad de los

Not $\{$ he/she $\}$-took into account - that the perversity of the hombres degrada hasta la inocencia de un idioma.

men degrades even the innocence of a language

' $\{\mathrm{He} / \mathrm{she}\}$ didn't take into account that the perversity of men degrades even the innocence of a language.'

(Maruja Torres, Hombres de lluvia; example from CREA)

b. Entraré sin que nadie se percate que soy yo.

I-will-come-in without that anybody - notices that is me

'I will come in without anyone noticing that it's me.'

(Volodia Teitelboim, En el país prohibido. Sin el permiso de Pinochet; example from CREA)

c. Está bien, lo haré si me pagas en metálico.

It-is ok, it I-will-do if to-me you-pay cash

'Ok, I will do it if you pay me cash.'

(Juan José Millás, Dos mujeres en Praga; example from CREA)

Furthermore, in Spanish, the sentence in the complement of a preposition can be a finite sentence headed by the explicit complementizer que or a non-finite sentence without an explicit complementizer: an infinitival sentence. The alternation between both classes of sentences has to do, among other factors, with the relation between the main subject and the subject of the embedded clause ${ }^{4}$. When they are not coreferential, the subordinated sentence is a finite one, as in $(10 \mathrm{a}, \mathrm{b})$; subordinated infinitival sentences usually occur when both subjects are coreferential, as in $(11 \mathrm{a}, \mathrm{b})$. However, in clear contrast to prepositions, (11c) shows that subordinated sentences headed by conjunctions exclude a non-finite verb:

4. The referential relation between both subjects is an important factor in the alternation between finite and non-finite subordinated sentences in Spanish, but it is not the only one. As we will see next, in sequences such as (12a) and (12b), a finite sentence with a coreferential subject is possible in some cases. See more about this topic in Hernanz (1999: 36.3.2.5) and Real Academia Española (2009: 26.4, 26.11). 
(11) a. Luis contaba con tener dos semanas más para terminar Luis expected - to-have two weeks more for to-finish el artículo. the paper 'Luis expected to have two more weeks to finish the paper.'

b. Entré sin percatarme de que estabas allí. I-came-in without to-realize of that you-were there 'I came in without realizing that you were there.'

c. *Solo lo haré si estar segura de que me pagarás Only it I-will-do if to-be sure of that to-me you-will-pay en metálico.

cash

'I will do it only if I am sure that you will pay me cash.'

As has been previously noted, most of the Spanish adverbial subordinating conjunctions are complex units, a good number of which contain the complementizer que. The possibility of substituting the constituent introduced by que is precisely one of the main tests used for determining if the complex unit is grammaticalized as a subordinating conjunction or, on the contrary, if it maintains the structure of a preposition (or another lexical item) followed by the complementizer that heads its sentential complement. Compare, for example, causal porque and puesto que ('because', 'since'). Despite the fact that the first of these units is written as a sole written word, the possibility of substituting the constituent introduced by que by an infinitival sentence, or even a pronoun or a DP, evidenced in (12a-d), shows that porque is not the result of a process of grammaticalizacion, but the graphic union of the preposition por ('because of') and the complementizer que:

(12) a. Le castigaron porque se había portado mal.

To-him they-punished because - he-had behaved bad

'He was punished because he had misbehaved.'

b. Le castigaron por haberse portado mal.

To-him they-punished because-of to-have behaved bad

'He was punished because of his misbehaving.'

c. Le castigaron por su mal comportamiento.

To-him they-punished because-of his bad behaviour

'He was punished because of his misbehaviour.'

d. Le castigaron por eso.

To-him they-punished because-of that

'He was punished because of that.'

By contrast, puesto que, formed with the past participle of poner ('put') and the complementizer, behaves like a compact grammaticalized unit. In this case, 
que does not introduce an independent constituent that could be substituted by another constituent, like a non-finite sentence, a pronoun or a DP:

(13) a. Avanzabas con mucha cautela, puesto que la penumbra You-moved-ahead with much caution, put that the half-darkness te impedia caminar con seguridad. to-you kept to-walk with confidence 'You moved ahead very cautiously, because the half-darkness kept you from walking with confidence.' (Jaime Martínez Salguero, El combate místico; example from CREA)

b. *Avanzabas con mucha cautela, puesto no poder caminar You-moved-ahead with much caution, put not to-can to-walk con seguridad. with confidence

c. *Avanzabas con mucha cautela, puesta ${ }^{5}$ la dificultad de You-moved-ahead with much caution, put the difficulty of caminar con seguridad. to-walk with safety

d. *Avanzabas con mucha cautela, puesto eso. You-moved-ahead with much caution, put that

\subsection{Adverbial subordinating conjunctions as a hybrid category}

Seeing the problems posed by both the hypotheses reviewed in the previous paragraphs, we will assume the proposal by Haumann (1997: ch. 8), who argues that adverbial subordinating conjunctions are a "conflating category, unifying properties of lexical and functional heads" (Haumann, 1997: 262). This category has in common with prepositions the fact that it has lexical content and it is associated with an argument structure. On the other hand, like complementizers, adverbial subordinating conjunctions take an extended projection of the verb as their complement. Assuming this proposal, the syntactic structure of an adverbial subordinated clause headed by an adverbial subordinanting conjunction (Subcon) would be as follows:

$$
\left[{ }_{\text {SubconP }} \text { Subcon }\left[{ }_{\mathrm{TP}} \ldots . \mathrm{T} \ldots\left[_{\mathrm{VP}} \ldots \mathrm{V} \ldots\right]\right]\right]
$$

In this structure, the adverbial subordinating conjunction takes as its complement the same sentential projection as complementizers, which we assume to be $\mathrm{TP}^{6}$.

5. The past participle in the feminine form is due to the fact that, in cases like this, it should agree with the DP.

6. In (14) we assume a standard analysis in which the sentential complement of C or Subcon is a projection of T(ime). For an argumentation in favour of this analysis (related to complementizer), see, among others, Adger (2003: 155-203). Fernández-Salgueiro (2008) also argues that the complement of adverbial subordinating conjunctions is TP. This author assumes that this class of conjunctions 
Nevertheless, in contrast to complementizers, adverbial subordinating conjunctions have lexical content. They express lexically the relation between the subordinated sentence and the main sentence, as is well known and has been previously referred to several times. Consequently, there must be a semantic relation between the adverbial subordinating conjunction and its sentential complement. As we will see in 5, it is this semantic relation that, ultimately, will explain why there are no locative subordinating conjunctions. But, first, we will review the structure of adverbial free relative clauses.

\section{Adverbial free relative clauses. Differences with adverbial clauses headed by conjunctions}

Relative clauses headed by relative adverbs may express three types of semantic relations: manner, time and place. This kind of subordinated sentences can occupy different positions with respect to the main sentence, but, basically, like any other relative clause, they can modify an antecedent, that is, they can appear as the complement of a substantive or an adverb, as in (15), or they may not have any overt antecedent, as in (16):

(15) a. [...] quizás llegue la hora cuando yo acabe suspirando por perhaps comes the hour when I end-up pining by "los buenos tiempos de la aviación".

"the good times of the aviation"

'Perhaps the time would come that I end up pining for "the good times of aviation".'

(Gilberto Chávez Jr., El batallador; example from CREA)

b. Ayer fui caminando a través de la jungla, allá donde Yesterday I-went walking through - the jungle, there where clarea la espesura.

thins-out the thicket

'Yesterday, I went walking through the jungle, where the thicket thins out.'

(Raúl Hernández, Los malditos; example from CREA)

c. Turbaba contemplar la manera como él la seducía. It-embarrassed to-see the way how he to-her seduced

'It was embarrassing to see the way he seduced her.'

(Germán Sánchez Espeso, En las alas de las mariposas; example from CREA)

and complementizers form part of the same class of words (along with coordinating conjunctions) and maintains that differences between them are due to individual lexical properties. We won't dwell on the discussion about the type and number of extended projections of the verb since this question does not necessarily affect the main conclusions of our work. See also, among others, Cinque (1999) and some of the contributions collected in Rizzi (ed.) (2004) or Guéron and Lecarme (eds.) (2004). 
(16) a. Eso es lo que sucedió cuando aquí me trajeron, comandante. That is what happened when here to-me they-brought, commander 'That is what happened when I was brought here, commander.' (Antonio Gala, Los invitados al jardin; example from CREA)

b. [...] la máquina no estaba donde había estado siempre. the machine not was where it-had been always 'The machine wasn't where it had been always.' (Gabriel García Márquez, Vivir para contarla; example from CREA)

c. Pensábamos las mismas cosas y queríamos que el mundo fuera We-thought the same things and we-wanted that the world was como nosotras soñábamos.

how we dreamt

'We thought the same things and we wanted the world to be as we dreamt it was.'

(Chavela Vargas, Y si quieres saber de mi pasado; example from CREA)

Relative clauses like those in (16) have usually been grouped, in many Spanish grammar books and references, with adverbial subordinated sentences like those analysed in the previous section ${ }^{7}$. However, there are basic differences between them regarding the fact that relative adverbs, in contrast with subordinating conjunctions, play a syntactic function in the subordinated sentence (locative complement or adjunct) and appear in the initial position of the construction by means of movement.

Adverbial relatives clauses in (16) are free relatives, that is, relative sentences that lack an explicit antecedent. There have been several types of proposals to account for the syntactic structure of free relatives, which could be grouped into basically two types of analyses. In the first of these analyses, there is a covert antecedent represented by an empty category. This proposal has been defended, among others, by Groos and Van Riemsdijk (1981) (see also Van Riemsdijk, 2000) and, for the Spanish language, Brucart (1999: 7.2.4.3). In the second analysis, defended by Bresnan and Grimshaw (1978), de Vries (2002) and Donati (2006), among others, the relative word would occupy the antecedent position. Adapting

7. A case in point of the confusion regarding the distinction between both classes of subordinated sentences is Real Academia Española (1928: § 401) where it can be read (referring to locative subordinated sentences): "[...] Son un caso particular de las oraciones adjetivas, con las cuales se confunden cuanto el antecedente es un sustantivo o un pronombre. Si digo: Esta es la casa en que nací, expreso mi pensamiento con una oración de relativo; y si sustituyo en ella el complemento en que por el adverbio donde, y digo: Esta es la casa donde nací, enuncio una subordinada circumstancial [...]" ('They are a particular case of adjective sentences, in which they are confused when the antecedent is a substantive or a pronoun. If I say: This is the house in which I was born, I express my thought by means of a relative sentence; and If I substitute in this sentence the complement in which for the adverb where, and I say: This is the house where I was born, I enunciate a circumstantial (adverbial) subordinated sentence'). These words are reproduced in Real Academia Española (1973: 537). 
these two analyses to the adverbial free relatives we are dealing with, we could schematically represent them as in $(17 \mathrm{a}, \mathrm{b})$ :
a. $\left[_{\mathrm{AdvP}} \mathrm{e}\left[\mathrm{CP}_{\mathrm{CP}} \operatorname{AdvRel}_{\mathrm{i}}\left[{ }_{\mathrm{TP}} \cdots \mathrm{t}_{\mathrm{i}} \ldots\right]\right]\right]$
b. $\left[_{\mathrm{AdvP}} \operatorname{AdvRel}_{\mathrm{i}}\left[\mathrm{CP} \ldots \mathrm{t}_{\mathrm{i}} \ldots\right]\right]$

In both analyses, the syntactic category of the highest constituent is $\mathrm{AdvP}^{8}$. In (17a), which corresponds to the first of the analyses previously referred to and fits the standard analysis of headed relative clauses, the relative adverb has moved to the specifier position of the relative clause that modifies a covert antecedent. In (17b), the adverbial relative has moved out of the CP to occupy the position of the antecedent ${ }^{9}$. Let us assume the more standard analysis, (17a), although the choice of one or another is not relevant for the purposes of our work. What we would like to emphasize is that, if we compare any of the structures in (17) with (14), we can notice the following differences between adverbial relative sentences and adverbial subordinated sentences headed by conjunctions:

1. The adverbial subordinating conjunction is generated in the initial position of the constituent it heads; in contrast, the relative adverb occupies the initial position via wh-movement.

2. The sentential projection CP in (17) is not selected by the head of the AdvP, in contrast with the TP complement in (14), which is lexically and categorially selected by the adverbial subordinating conjunction.

Moreover, there is evidence, in many other senses, that subordinating conjunctions and relative adverbs, and, consequently the constructions they introduce, are syntactic elements with dissimilar properties. Some of them are herewith exposed $^{10}$ :

1. All relative words, and, particularly, all relative adverbs, can appear in constructions with an explicit antecedent, like those mentioned above in (15). In contrast, adverbial sentences headed by conjunctions cannot modify an alleged antecedent, as the examples in (18) show:

8. A competing analysis would hold that the whole constituent is a CP. However, this analysis is usually rejected by arguing that the distribution of free relatives is similar to that of the constituents headed by the antecedent of full relatives, and not that of other CP constituents, such as declarative or interrogative subordinated sentences (see Donati, 2006: $§ 5$ ).

9. In a conservative version of this analysis, the AdvRel would occupy the specifier position of the AdvP, after moving from the specifier position of the CP. Nevertheless, de Vries (2002) considers it to move to the head position. Donati (2006), who argues in favour of the possibility that wh-movement operates with heads, holds that, in free relatives, the moved constituent is a head, and not a phrase.

10. See Pavón Lucero (2003b: chapters 6 and 7) for a comparison, using similar arguments as those exposed here, between temporal constructions headed by prepositions and subordinating conjunctions, on the one hand, and temporal constructions headed by relative adverbs, on the other hand. 
(18) a. *La nueva escuela funcionará en el supuesto si se terminan las The new school will-work on the assumption if - finish the obras a tiempo. works on time

b. *La nueva escuela funcionará pese al inconveniente aunque no The new scholl will-work despite the inconvenience although not se hayan terminado las obras.

- have finished the works

2. The relative adverb can be moved to its initial sentence position from different levels in subordinated sentence. If this one contains another subordinated sentence as a complement of the verb, the resulting construction may be ambiguous. For example, in (19a) we could obtain two interpretations corresponding to the structures in (19b) and (19c). In (19b), in which the relative adverb has been moved from the highest subordinated sentence, we would understand that Julia's arrival happened during the time while Marta was saying something; in (19c), in which the relative adverb has been moved from the lowest subordinated sentence, we obtain the meaning that Julia's arrival happened at the time Juan was supposed to arrive:

(19) a. Julia llegó cuando Marta decía que llegaría Juan. Julia arrived when Marta said that would-arrive Juan

b. $\left[_{\mathrm{AdvP}} \mathrm{e}\left[_{\mathrm{CP}}\right.\right.$ cuando $_{\mathrm{i}}\left[{ }_{\mathrm{C}}, \mathrm{C}\left[_{\mathrm{TP} 1}\right.\right.$ Marta decía $\mathrm{t}_{\mathrm{i}}\left[_{\mathrm{CP} 2}\right.$ que $\left[_{\mathrm{TP} 2}\right.$ llegaría Juan $\left.\left.\left.\left.]\right]\right]\right]\right]$ c. $\left[_{\mathrm{AdvP}}\right.$ e $\left[_{\mathrm{CP}}\right.$ cuando $_{\mathrm{i}}\left[{ }_{\mathrm{C}}, \mathrm{C}\left[_{\mathrm{TP} 1}\right.\right.$ Marta decía $\left[_{\mathrm{CP} 2}\right.$ que $\left[_{\mathrm{TP} 2}\right.$ llegaría Juan $\left.\left.\left.\left.\left.\mathrm{t}_{\mathrm{i}}\right]\right]\right]\right]\right]$

In clear contrast to sentences like (19a), conditional and concessive sentences like those in (20a) and (20b) lack the possibility of an ambiguous interpretation. In the only plausible interpretation for these sentences, the condition or the impediment for calling is the fact of saying something, and not what is said:

(20) a. Llámame si dices que hablas con ella. Call-me if you-say that you-talk to her

b. Llámame aunque digas que no hablarás con ella. Call-me even-if you-say that not you-will-talk to her

3. Our last argument to show the contrast between relative adverbs and subordinating conjunctions has to do with the fact that the former, but not the latter, have the capacity of referring anaphorically to another constituent. Sentences headed by relative adverbs may form pseudo-cleft-sentences like those in (21); this construction is excluded in the case of subordinating conjunctions, as (22) shows: 
(21) a. A las ocho fue cuando llegaron.

At the eight it-was when they-arrived

'It was eight when they arrived.'

b. En tu casa será donde nos veremos.

In your home it-will-be where to-ourselves we-will-see

'It will be in your home where we will see each other'

c. Así es como lo pintaron.

This-way is how to-it they-painted

'This is the way they painted it.'

(22) a. *(En) ese supuesto es si se terminan las obras a tiempo. (Cf. La nueva escuela funcionará si se terminan las obras a tiempo.)

Lit. 'It is (in) that case if the works finish on time.' ( $C f$. 'The new school will be operative if the works finish on time.')

b. *(Pese a) ese impedimento es aunque no se hayan terminado las obras. ( $C f$. La nueva escuela funcionará aunque no se hayan terminado las obras.) Lit. 'It is (in spite of) that impediment even thougt the works haven't finished on time.' ( $C f$. 'The new school will be operative even though the works haven't finished on time.')

In conclusion, we have reviewed two types of so-called adverbial subordinated sentences: those introduced by subordinating conjunctions and those introduced by relative adverbs. The former type of adverbial subordinated sentences may express several kinds of semantic relations with respect to the main clause: condition, concession, cause, purpose, time and so on. Adverbial relative sentences can express time, place and manner ${ }^{11}$. Given that dissimilarity, there would be several questions we could formulate regarding why, apparently, some semantic relations are restricted to one type of construction and excluded from the other. In the following, we will try to answer only one of these possible questions: why are there no locative conjunctions in Spanish? As we will see, the answer has to do with the relation between the semantic and syntactic structure of the constituents headed by adverbial subordinating conjunctions.

11. Apparently, the only semantic relations that can be expressed both by means of a free relative clause and by a clause headed by an adverbial subordinated sentence are temporal relations. In Spanish, there are a considerable number of temporal subordinators traditionally classified as conjunctions: apenas ('hardly'), mientras ('while'), en tanto que ('insofar as'), al tiempo que ('while'), etc. In Pavón Lucero (2003b: VII.5), we presented some arguments putting in evidence that mientras is an adverbial subordinating conjunction, by comparing this lexical unit to the relative adverb cuando ('when'). Probably similar arguments could be made with regard to other temporal subordinators. At any rate, there are likewise important similarities between them and relative adverbs, as Real Academia Española (2009: 31.13e-h) points out. 


\section{The semantics of Place}

As we have previously put forward, the non-existence of locative subordinating conjunctions in Spanish is due to the incompatibility between the semantic structure of locative constituents and the semantic and syntactic properties of subordinating conjunctions and, accordingly, the semantic and syntactic properties of the constituents they introduce.

Let us first consider the semantic structure of locative constructions. In order to account for it, we will assume the proposals by Jackendoff $(1983,1990,2002)$, in the theoretical framework of Conceptual Semantics. Based on these theoretical assumptions, we will take (23a) as the basic conceptual structure for the semantic category Place ${ }^{12}$ (Jackendoff, 1983: 162). According to this structure, Place could be accounted for as a Place function which takes, as its internal argument, the semantic category Thing. This would be the conceptual structure that would correspond to a PP like (23b): the preposition en ('on') would correspond to the Place function, and the DP la mesa ('the table'), would correspond to the internal argument ${ }^{13}$ :

(23) a. $\left[_{\text {Place }}\right.$ PLACE-FUnCtION [Thing X]]

b. ${ }_{\mathrm{PP}}$ En [DP la mesa]]

Let us now return to the lexical-syntactic properties of subordinating conjunctions. In 3.3, we have assumed, following Haumann (1997), that adverbial subordinating conjunctions constitute a hybrid category which exhibits properties of both the lexical and functional categories. As with lexical categories, like prepositions, adverbial subordinating conjunctions have lexical content and are associated with an argument structure; as with functional categories like complementizers, adverbial subordinating conjunctions take an extended projection of the verb (TP) as its complement. The structure of the sentential constituent headed by a subordinating conjunction is (14), repeated here:

12. We will use initial capital letters for conceptual-semantic categories.

13. In (23a), we try to illustrate a simple Place-function, which is sufficient for our purposes. Nevertheless, as Jackendoff (1983) points out, there are more complex spatial concepts, such as those based on the conceptual category Path, that can be expressed in prepositional phrases like two miles from here. In any case, the conceptual category corresponding to the internal argument is, ultimately, Thing. On the other hand, the conceptual structure corresponding to a PP like (23b) would also contain an external argument, which would correspond to the object located in the place expressed by the PP or the event/state occurring in that place. In the mapping from this conceptual structure to the syntax, this external argument would correspond, for example, to the subject of a sentence like (ia), el libro ('the book'), or to the whole sentence in (ib):

(i) a. El libro está en la mesa.

The book is on the table

b. Dos hormigas correteaban en la mesa.

Two ants scampered on the table 
(14) $\left[_{\text {SubconP }}\right.$ Subcon $\left.\left[{ }_{\mathrm{TP}} \ldots \mathrm{T} \ldots\left[_{\mathrm{VP}} \ldots . . ..\right]\right]\right]$

A structure like this one matches a subjacent semantic structure consisting of a semantic function and an internal argument. The semantic category of the latter, which invariably has to correspond to the syntactic category TP, must be Situation (Event or State). The semantic category corresponding to the subordinating conjunction would vary depending on the concrete lexical item; for instance: si matches Condition and puesto que matches Cause. The lexical conceptual structure corresponding to (14) would be, temptatively, (24) ${ }^{14}$ :

(24) a. $\left[_{\{\text {Cause/Condition/... }\}}\{\right.$ CAUSE/ CONDITION/... $\}$-FUNCTION $\left[\left[_{\text {Event/State }} \mathrm{X}\right]\right]$

If we confront now (14) and (24), we can easily see the reason why there are no subordinating locative conjunctions: because the constituent TP complement of a subordinating conjunction would not be able to correspond to the semantic category Thing; an extended projection of the verb could only correspond to semantic categories like State or Event. As a matter of fact, we could not find a syntactic structure that would correspond to a conceptual structure in which a Place function would take an Event or a State as its internal argument. Prepositional or Adverbial Phrases corresponding to the ontological category Place, like those in (25a-b), have a DP as complement of the preposition. There are, on the other hand, lexical items which lexicalize the place function and the internal argument in only one word, such as the deictic locative adverbs in (25c):

(25) a. Sobre el tejado.

On the roof

b. Debajo de la cama.

Under of the bed

c. Aquí, ahí.

Here, there

As we have seen in 4, a free relative clause can denote a Place. In that case, the meaning of the construction could not be decomposed as a Place-function that takes a Thing as an internal argument. As Jackendoff (2002: 384) points out: "[...] a relative clause identifies an individual by virtue of his/her participation in the Situation (State or Event) denoted by the clause". In sentences like (16b) above,

14. As in (23a) above, the external argument, which in these cases would be matched by the main sentence, is not represented here for simplicity, seeing that we are concentrating on the internal structure of the adverbial subordinated clause. Furthermore, we express semantic categories like Cause or Condition as if they were simple categories, despite the fact that they probably are complex categories that could be decomposed in other simpler categories. At any rate, the most relevant fact for our purposes is that the internal argument would correspond to the ontological categories Event or State in any case. 
repeated here as (26a), the Place denoted by the adverb phrase headed by donde is determined by virtue of the fact that the State described in the relative sentence is necessarily related to a Place. Following Jackendoff (2002: 384-386), we can account for the semantics of a sentence like (26a) by recourse to the formal logic notation for lambda-extraction. Temptatively, we propose a conceptual structure like (26b) for the free relative clause donde había estado siempre ("where it had been always'):

(26) a. La máquina no estaba donde había estado siempre.

b.

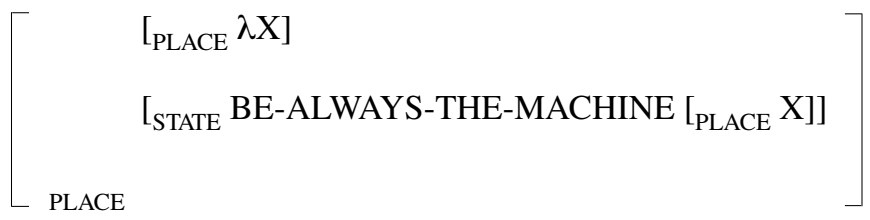

In this conceptual representation, the locative meaning of the sentence is represented in the first line as a Place that is determined by means of its participation in a more complex semantic representation. The second line shows this representation; that is, it describes how the Place denotation is obtained by means of a State which occurs in that Place.

If the answer proposed here to the question which opens this paper is correct, it would be the case that there are no locative adverbial subordinating conjunctions not only in Spanish, but in any other language. Adverbial subordinating conjunctions have two properties that characterise them as a particular class of words: on the one hand, they take an extended projection of the verb as a complement: TP; on the other hand, they have lexical content and are associated with an argument structure. From a conceptual semantic point of view, adverbial subordinating conjunctions would correspond, like prepositions, to a semantic function that takes a semantic category as an argument.

We have seen as well that the semantic category Place can be decomposed in a function of Place that takes a Thing as internal argument. Locative prepositions, as well as some locative adverbs, would correspond, from this point of view, to Place-functions that take Things as arguments. Adverbial subordinating conjunctions could likewise be considered the lexicalization of functions of different types of semantic categories. In any case, these functions must take Situations (Events or States) as internal arguments, since adverbial subordinating conjunctions, as well as complementizers, invariably take a TP as a complement. Seeing that a Place-function must take a Thing as an internal argument, the impossibility of having locative subordinating conjunctions is naturally explained.

This is, obviously, a theoretical consequence of the semantic and syntactic characterization of adverbial subordinating conjunctions proposed here, and it would be necessary to carry out significant research in order to check if this conclusion is empirically supported. However, there are some indications in European languages that point in the same direction. In most European languages, locative subordina- 
tors predominantly consist of one monomorphemic word (see Kortmann 1997, especially chapter 7), in contrast with other adverbial subordinators. On the other hand, locative subordinators in most European languages are formally identical to locative interrogative words. Here we have some examples:

(27) a. Locative relative adverbs: donde (Spanish); on (Catalan); dove (Italian); où (French); where (English); wo (German); waar (Dutch); gdzie (Polish).

b. Locative interrogative adverbs: dónde (Spanish); on (Catalan); dove (Italian); où (French); where (English); wo (German); waar (Dutch); gdzie (Polish).

The fact that locative subordinators are predominantly simple words could be closely related to the basic semantic structure of spatial expressions, which takes a Thing as internal argument. Many adverbial subordinators are originated in several types of constructions that contain a clausal complement (mostly phrases headed by simple or complex prepositions and adverbs; that is the origin of Spanish a condición de que, porque, siempre que, etc.). But, as we have previously seen, a clausal structure cannot correspond to the semantic category Thing ${ }^{15}$. As to the formal similarity between locative subordinators and interrogative words, it is a consequence that relative and interrogative adverbs are basically the same class of words that are characterized by being moved in the sentence, whether in the syntax or in the logical form.

\section{Concluding remarks}

In this paper, we have reviewed the syntactic categorial properties of adverbial subordinating conjunctions and assumed the proposal, by Haumann (1997), that they unify properties of lexical and functional heads: specifically, properties of prepositions and complementizers. We have also compared the properties of sentences introduced by adverbial subordinating conjunctions with the properties of adverbial free relative sentences, which, in contrast to the former, can express spatial relations. After that, we have outlined the semantic structure of spatial expressions and offered an answer to the question which opens this paper. The non-existence of locative adverbial subordinating conjunctions is due to the incompatibility between the semantic structure of spatial expressions and the syntactic structure of sentences introduced by this type of conjunctions.

15. In some languages, there is more than one locative relative-interrogative adverbs, like English whence. Furthermore, there are also complex units based on a relative-interrogative adverb modified by a preposition, like German wohin (lit. where-to), woher (lit. where-from). 


\section{References}

Adger, David (2003). Core Syntax. A Minimalist Approach. Oxford: Oxford University Press.

Bello, Andrés (1847). Gramática de la lengua castellana destinada al uso de los americanos. Edited by Ramón Trujillo, Cabildo Insular de Tenerife, 1981.

Bresnan, Joan; Grimshaw, Jane (1978). "The syntax of free relatives in English". Linguistic Inquiry 9/3: 331-391.

Brucart, José María (1999). "La estructura del sintagma nominal: las oraciones de relativo”. In: Bosque, Ignacio; Demonte, Violeta (dirs.). Gramática descriptiva de la lengua española. Madrid: Espasa-Calpe, pp. 395-522.

Cinque, Giuglielmo (1999). Adverbs and Functional Heads. A Cross-Linguistic Perspective. Oxford-New York: Oxford University Press.

CREA: Real Academia Española. Banco de datos (CREA) [en línea]. Corpus de referencia del español actual. <http://www.rae.es>

Emonds, Joseph E. (1985). A Unified Theory of Syntactic Categories. Dordrecht: Foris.

Fernández-Salgueiro, Gerardo (2008). Aspects of the syntax of (TP-) coordination, across-the-board extraction, and parasitic gaps. Doctoral dissertation. University of Michigan.

García Fernández, Luis (1999). "Los complementos adverbiales temporales. La subordinación temporal”. In: Bosque, Ignacio; Demonte, Violeta (dirs.). Gramática descriptiva de la lengua española. Madrid: Espasa-Calpe, pp. 3129-3208.

Groos, Anneke; van Riemsdijk, Henk (1981). "Matching effects in free relatives: a parameter of core grammar". In: Belletti, Adriana et al. (eds.). Theory of Markedness in Generative Grammar. Pisa: Scuola Normale Superiore, pp. 171-216.

Guéron, Jacqueline; Lecarme, Jacqueline (eds.) (2004). The Syntax of Time. Cambridge, MA: MIT Press.

Haegeman, Liliane (2007). "Operator movement and topicalisation in adverbial clauses". Folia Linguistica 41/3-4: 279-325

Haumann, Dagmar (1997). The Syntax of Subordination. Tübingen: Max Niemeyer Verlag.

Hendrick, Randall (1976). "Prepositions and the X-bar Theory". In: Emonds, Joseph (ed.). Proposals for Semantic and Syntactic Theory. Los Angeles: UCLA Papers in Syntax, pp. 95-122.

Hernanz, Ma Lluïsa (1999). "El infinitivo”. In: Bosque, Ignacio; Demonte, Violeta (dirs.). Gramática descriptiva de la lengua española. Madrid: Espasa-Calpe, pp. 2196-2356.

Hjemslev, Louis (1928). Principes de grammaire générale. København: Munksgaard.

Jackendoff, Ray (1973). “The Base Rules for Prepositional Phrases”. In: Anderson, Stephen R.; Kiparsky, Paul (eds.). A Festschrift for Morris Halle. New York: Holt, Rinehart \& Winston, pp. 345-356.

Jackendoff, Ray (1977). X-Bar Syntax: A Study of Phrase Structure. Cambridge, MA: MIT Press.

Jackendoff, Ray (1983). Semantics and Cognition. Cambridge, MA: MIT Press.

Jackendoff, Ray (1990). Semantic Structures. Cambridge, MA: MIT Press.

Jackendoff, Ray (2002). Foundations of Language. Oxford: Oxford University Press. Jespersen, Otto (1924). The Philosophy of Grammar. London: Allen and Unwin. 
Kortmann, Bernd (1997). Adverbial Subordination. A Typology and History of Adverbial Subordinators Based on European Languages. Berlin-New York: Mouton de Gruyter.

Larson, Richard K. (1990). "Extraction and Multiple Selection in PP". The Linguistic Review 7: 169-182.

Lasnik, Howard; Saito, Mamuro (1992). Move $\alpha$. Cambridge, MA: The MIT Press.

Pavón Lucero, Ma Victoria (2003a). "Relaciones entre sintaxis y semántica: de por qué no existen conjunciones subordinantes locativas en español". In: Muñoz Núñez, M. D.; Rodríguez-Piñero Alcalá, A. I.; Fernández Smith, G.; Benítez Soto, V. (eds.). IV Congreso de Lingüística General. Cádiz, del 3 al 6 de abril de 2000. Cádiz: Universidad de Cádiz-Universidad de Alcalá, pp. 2053-2062.

Pavón Lucero, Ma Victoria (2003b). Sintaxis de las partículas. Madrid: Visor.

Pottier, Bernard (1962). Systematique des éléments de relation. Paris: Klinksieck.

Real Academia Española (1928). Gramática de la lengua española. Madrid: Hernando.

Real Academia Española (1973). Esbozo de una nueva gramática de la lengua española. Madrid: Espasa Calpe.

Real Academia Española (2009). Nueva gramática de la lengua española. Madrid: Espasa Calpe.

Riemsdijk, Henk van (1981). "Free relatives". In: Everaert, Martin; Riemsdijk, Henk van (eds.). The Blackwell Companion to Syntax II. Oxford: Blackwell, pp. 338-382.

Rigau, Gemma (1984). "De com si no és conjunció i d'altres elements interrogatius". Estudis gramaticals I: 249-278.

Rizzi, Luigi (ed.) (2004). The Structure of CP and IP. The Cartography of Syntactic Structures, volume 2. Oxford-New York: Oxford University Press.

Vries, Mark de (2002). The Syntax of Relativization. Utrecht: LOT. 